\title{
A CONSTRUÇÃO DO OLHAR DO TURISTA: UMA ANÁLISE ICONOGRÁFICA A PARTIR DA REVISTA A ESTRADA DE RODAGEM (1922 - 1923)
}

\author{
Vânia da Silva \\ Mestra em Turismo \\ Escola de Artes, Ciências e Humanidades da Universidade de São Paulo (EACH-USP) \\ Arquivo Público do Estado de São Paulo \\ vaniadasilva@alumni.usp.br \\ Thiago Allis \\ Doutor em Arquitetura e Urbanismo \\ Escola de Artes, Ciências e Humanidades da Universidade de São Paulo (EACH-USP) \\ thiagoallis@usp.br
}

\section{Resumo}

Objetivo do estudo: Entender o papel da imprensa especializada no desenvolvimento do turismo, particularmente quanto à emergência do rodoviarismo no início do século XX no estado de São Paulo.

Metodologia/abordagem: Investigação iconográfica, composta por análise iconográfica e interpretação iconológica (Kossoy, 2009) de imagens e textos sobre turismo, e de seu contexto, presentes na revista “A Estrada de Rodagem” (1922-1923), órgão de propaganda da Associação de Estradas de Rodagem (AER). Para embasar a interpretação iconológica, foram utilizados conceitos quanto à construção do olhar do turista (Urry \& Larsen, 2011), especialmente às viagens imaginativas. Também estão presentes os referenciais que ajudam a conhecer o contexto de construção de estradas do início do século XX, período que propiciou a criação da Revista.

Originalidade/Relevância: A análise de imagens da imprensa com a metodologia de Kossoy (2009) é inédita nos estudos relativos à história do turismo. Compreender o papel do turismo no processo mostra sua relevância na própria criação e consolidação de culturas rodoviárias emergentes, que, como o estudo mostra, tiveram nas narrativas (proto)turísticas parte de seu argumento.

Principais resultados: Identificaram-se aspectos que, de alguma forma, ajudaram a difundir as viagens em automóvel pelas estradas paulistas recém-construídas, ao mesmo tempo que o turismo - ainda incipiente - era apontado como prática social e estratégia de comunicação.

Contribuições teóricas/metodológicas: O estudo aborda o conceito de viagens imaginativas aliado a uma metodologia de análise de fotografia na imprensa da década de 1920. Traz à discussão as mobilidades como categoria de análise complexa, em associação com estudos de comunicação.

Palavras-chave: História do turismo. Investigação iconográfica. Estrada de rodagem. São Paulo (Estado).

\section{Cite como}

American Psychological Association (APA)

Silva, V., \& Allis, T. (2021, set./dez.). A construção do olhar do turista: uma análise iconográfica a partir da revista a estrada de rodagem (1922 - 1923). PODIUM Sport, Leisure and Tourism Review, São Paulo, 10(3), 84-113. https://doi.org/10.5585/podium.v10i3.17679. 
Silva, V., \& Allis, T. (2021, set./dez.). A construção do olhar do turista: uma análise iconográfica a partir da revista a estrada de rodagem (1922 - 1923)

\title{
THE CONSTRUCTION OF TOURIST GAZE: AN ICONOGRAPHIC ANALYSIS FROM THE MAGAZINE A ESTRADA DE RODAGEM (1922 - 1923)
}

\begin{abstract}
Objective: Understand the role of the specialized press in the development of tourism, particularly about the emergence of highways culture in the early $20^{\text {th }}$ century in Sao Paulo.

Methodology/approach: an iconographic investigation was conducted, consisting of iconographic analysis and iconological interpretation of images and texts about tourism, as well as their context, present in the magazine "A Estrada de Rodagem", between 1922 and 1923. To support the iconological interpretation, concepts based on the "tourist gaze" (Urry \& Larsen, 2011) have been employed, especially the imaginative travel enhanced by the images displayed in this magazine. Also present are references that help to understand the context of the construction of highways in the state of São Paulo at the beginning of the $20^{\text {th }}$ century, a period that led to the creation of the magazine.

Relevance: The analysis of press images using Kossoy's (2009) methodology is unprecedented in studies related to the history of tourism. Understanding the role of tourism in the process shows its relevance in the creation and consolidation of emerging road cultures, which, as the study shows, had part of their argument in (proto)tourism narratives.

Main results: As a result, the study made it possible to identify aspects that, in some way, helped to spread car culture on newly built São Paulo roads, at the same time that tourism - still incipient - was pointed out as a social practice and communication strategy.

Theorical/methodological contributions: This study uses the concept of imaginative travel combined with a photography analysis methodology to understand tourism published in the press of early 1920's.

Keywords: Tourism history. Iconographic research. Highways. São Paulo (State).

\section{LA CONSTRUCCIÓN DE LA MIRADA DEL TURISTA: UN ANÁLISIS ICONOGRÁFICO DE LA REVISTA A ESTRADA DE RODAGEM (1922 - 1923)}

Objetivo: El objetivo de este trabajo es comprender el papel de la prensa especializada en el desarrollo del turismo, particularmente con respecto a la aparición del tráfico por carretera a principios del siglo XX en São Paulo.

Metodología/ enfoque: Se realizó una investigación iconográfica, que consistió en el análisis iconográfico y la interpretación iconológica de imágenes y textos sobre turismo, así como su contexto, presente en la revista "A Estrada de Rodagem", entre 1922 y 1923. La revista fue el organo de publicidad de la Associação de Estradas de Rodagem (AER). Para apoyar la interpretación iconológica, se utilizaron conceptos con respecto a la construcción de la "mirada del turista" (Urry y Larsen, 2011), especialmente los viajes imaginativos. También están presentes referencias que ayudan a comprender el contexto de la construcción de carreteras en el estado de São Paulo a principios del siglo XX, un período que condujo a la creación y desarrollo de la revista.

Originalidad/ relevância: El análisis de prensa, utilizando la metodologia de Kossoy (2009) no tiene precedentes en estudios relacionados com la historia del turismo.

Resultados principales: El estudio permitió identificar aspectos que, de alguna manera, ayudaron a difundir el viaje en automóvil por las carreteras de São Paulo recién construidas, al mismo tiempo que el turismo, aún incipiente, se señaló como una práctica social y una estrategia de comunicación.

Contribuciones teóricas/ metodológicas: El estúdio utiliza el concepto de viaje imaginativo combinado con una metodologia para analizar la fotografia de la prensa de los años veinte.

Palabras clave: História del turismo. Investigación iconográfica. Carreteras. São Paulo (Estado). 
Silva, V., \& Allis, T. (2021, set./dez.). A construção do olhar do turista: uma análise iconográfica a partir da revista a estrada de rodagem $(1922-1923)$

\section{Introdução}

É desnecessário lembrar que, na literatura clássica sobre a história do turismo - no mundo ou no Brasil -, o papel das transformações sociais e tecnológicas é central para a construção e desenvolvimento da atividade. Ao mesmo tempo, parece haver uma lacuna especialmente no Brasil - que chama atenção para o peso que a emergência de uma cultura rodoviarista, como condicionante para muitas das práticas turísticas vigentes. Particularmente no caso do estado de São Paulo, que tem uma das redes viárias mais desenvolvidas do país (e também já foi o estado com maior malha ferroviária), assume-se como óbvia a relação do carro com o turismo, mas pouco se fez para entender como estes elementos se constituíram e se alimentaram ao longo da história recente - ou seja, desde o início do século XX, quando São Paulo e o Brasil embarcavam em um período de mudanças estruturais.

Neste sentido, analisar imagens, além dos textos de uma revista impressa, é fundamental para entender o conjunto de informações de uma publicação. Se for uma revista publicada há quase um século, como neste caso, é necessário trazer o contexto do período em que ela foi publicada para resgatar informações que não estejam aparentes nas imagens. Partindo desta ideia, este trabalho propõe uma análise de fotografias reproduzidas na revista "A Estrada de Rodagem", publicação da Associação de Estradas de Rodagem (AER), entidade paulista atuante de 1919 a 1930, que tinha por objetivo difundir a construção e manutenção de estradas, além do uso do automóvel para diversas finalidades, inclusive para o nascente turismo.

É importante destacar que esta revista não tinha como enfoque único o turismo, mas abria espaço para o assunto (com uma seção especial, inclusive), desde que se tratasse de viagens em automóvel. Essa combinação de origem, de alguma maneira põe de manifesto como as narrativas turísticas eram relevantes para a construção de uma cultura rodoviária - ainda que, como se verá, a própria ideia de turismo fosse algo relativamente abstrato na sociedade de então.

A metodologia para a análise das imagens ancora-se no modelo de investigação iconográfica, composto por análise iconográfica e interpretação iconológica (Kossoy, 2009). Para dar embasamento a essa interpretação empregam-se conceitos relacionados à construção do olhar do turista (Urry \& Larsen, 2011), principalmente às viagens imaginativas (imaginative travels) feitas pelas fotografias da revista (Urry, 2007). Esses conceitos estarão aliados ao contexto de construção de estradas de rodagem no estado de São Paulo do início do século XX, período que propiciou a criação e o desenvolvimento da revista da AER. Para a análise iconográfica e interpretação iconológica foram selecionadas cinco reportagens, publicadas em 
Silva, V., \& Allis, T. (2021, set./dez.). A construção do olhar do turista: uma análise iconográfica a partir da revista a estrada de rodagem $(1922-1923)$

“A Estrada de Rodagem”, entre os anos de 1922 e 1923, cujas fotos ajudam a mostrar a pluralidade de assuntos tratados na revista e, ainda mais importante, como se constituía o imaginário turístico em associação com a emergente cultura rodoviária.

\section{São Paulo e o rodoviarismo no início do século XX: nasce "A Estrada de Rodagem”}

A construção de estradas de rodagem no estado de São Paulo teve grande incentivo no governo de Washington Luís (1920-1924). Sua política rodoviarista já havia resultado na expansão viária na cidade de São Paulo enquanto foi prefeito, entre 1914 e 1919 (Pereira, 2010, p. 193). Elegeu-se presidente do estado ${ }^{1}$ em 1920 com o lema "Governar é abrir estradas", com o propósito de povoar terras paulistas e, segundo sua propaganda, oferecer uma alternativa de maior alcance às estradas de ferro que já estavam em pleno funcionamento desde o século XIX. No final de seu governo, havia cerca de 1.200 quilômetros de novas estradas de rodagem estaduais trafegáveis (Debes, 1993, p. 322).

Com a expansão dessas e de outras estradas pelo estado, o uso do automóvel (ainda para a elite que podia comprá-lo) passou a ser difundido por entidades civis como o Automóvel Clube e a Associação Permanente de Estradas de Rodagem (APER). Esta entidade, expressão da elite política e econômica paulista, divulgava em sua revista mensal as informações sobre a evolução das estradas paulistas e de outros estados, dados técnicos quanto ao transporte de cargas e de passageiros, entre outras estatísticas, além de estimular o uso do automóvel para práticas turísticas emergentes, ainda envoltas em algum espírito aventureiro (Silva, 2019).

A APER foi uma entidade civil paulista que se articulou para promover ações em prol da construção, manutenção e propaganda de estradas no estado de São Paulo. Foi atuante por cerca de dez anos, entre 1919 e 1930. A partir de 1923 foi renomeada como Associação de Estradas de Rodagem (AER) e nos últimos anos de sua existência passou a se chamar Associação Paulista de Boas Estradas (APBE). Sua revista mensal circulou entre 1921 e 1924 como "A Estrada de Rodagem" e de meados de 1924 a 1928 com o nome de "Boas Estradas", tendo exemplares vendidos em bancas e por assinatura para associados e não-associados, gerando 80 edições em quase sete anos de existência. A partir de 1928 a publicação transformou-se em um jornal semanal.

Ao chegar ao Brasil no final do século XIX, o automóvel trazia a ideia de modernidade. Essa não era uma característica regional, e sim uma "linha cultural comum a todos os países,

${ }^{1}$ Presidente do Estado era a denominação equivalente a governador que prevaleceu durante a Primeira República (1889-1930). 
Silva, V., \& Allis, T. (2021, set./dez.). A construção do olhar do turista: uma análise iconográfica a partir da revista a estrada de rodagem $(1922-1923)$

associando os veículos a motor às ideias de velocidade, independência e liberdade" (Reis, 1998, p. 35). Portanto, a AER precisava de um canal de comunicação com seus associados em que pudesse difundir as ideias do rodoviarismo (conceito ligado à expansão de rodovias ou estradas de rodagem, como eram então denominadas). Dessa forma, em abril de 1921, o grupo de diretores apresentou a primeira edição da revista da entidade, chamada "A Estrada de Rodagem".

Essa publicação ressaltava o progresso e o desenvolvimento que as estradas poderiam trazer para o estado de São Paulo. Contava com anúncios de automóveis importados, de peças e de outras máquinas como tratores e colheitadeiras. Também eram comuns os anúncios de representantes do comércio paulistano, como a Mappin Stores. Tinha seções sobre eventos como raids, congressos e feiras automobilísticas, sobre a expansão de rodovias no Brasil e no exterior e convocava a colaboração dos associados em diversas oportunidades, inclusive para que enviassem relatos e fotografias de seus passeios de automóvel. Entre as seções mais constantes da revista estão: "Municípios de São Paulo" e "Estados do Brasil”, sobre as estradas de cada região; "Pelo mundo afora", sobre desenvolvimento de estradas em outros países; e as que são mais curiosas para esta pesquisa como "Turismo" e "Itinerários da APER" (Silva, 2019).

Um dos enfoques principais da revista era a exploração - sofisticada para época - dos aspectos imagéticos das incipientes viagens rodoviárias, alimentando formas elementares de turismo, que passariam a ser dominantes nas décadas seguintes e até os dias de hoje.

\section{O turismo e a imprensa: viagens imaginativas pelas imagens das revistas}

O conceito de viagens imaginativas (imaginative travels) é colocado por Urry (2007) como aquelas que ocorrem a partir da leitura dos textos e das imagens publicadas em jornais e revistas, sejam ilustrações ou fotografias e, mais recentemente, também pela imagem em movimento da TV. Por meio desses apelos visuais, o leitor se imagina naquele cenário da fotografia, despertando o desejo de realizar a viagem "corporal" (corporeal travel), para viver fisicamente a experiência despertada pela imaginação. Esse conceito é reforçado em 2011, com “Tourist Gaze 3.0”, de Urry e Larsen (p. 168, livre tradução):

A fotografia parece ser um meio de transcrever a realidade (...). Parece que a câmera não mente. O realismo das fotografias tornou essa viagem real e sedutora. Visitar lugares através de fotografias às vezes era mais ou menos tão bom quanto olhar a realidade com os próprios olhos. 
Silva, V., \& Allis, T. (2021, set./dez.). A construção do olhar do turista: uma análise iconográfica a partir da revista a estrada de rodagem (1922 - 1923)

Urry e Larsen (2011, p. 17) enfatizam que o olhar do turista também é construído socialmente. As pessoas veem o mundo através de um filtro particular formado por ideias, conhecimentos, desejos e expectativas, moldados por fatores diversos, como pela classe social, gênero, nacionalidade, idade e escolaridade. Então, o olhar do turista não reflete a realidade, mas aquilo que ele vê conforme seu olhar é moldado social e culturalmente.

Ao fotografar uma viagem, o turista detém a prova incontestável de que esteve naquele lugar, "de que a programação foi cumprida, de que houve diversão" (Sontag, 2004, p. 19). Principalmente no início do século passado, quando não era possível alterar uma fotografia de maneira convincente.

Trazendo a discussão para o campo da história, pesquisar o turismo pelo Brasil no início do século XX é desafiador por ser uma atividade pouco organizada no período e pela pulverização das fontes de pesquisa. Os registros mais conhecidos são os do Rio de Janeiro, capital do país no período. Segundo Castro (2001), a imagem do Rio de Janeiro como destino turístico é uma construção cultural que passou por mudanças ao longo do tempo, com a apreciação do turista migrando da área central para as praias, por exemplo. Neste sentido, as imagens da imprensa colaboram para a construção desse olhar.

No caso da revista em análise, seria possível verificar como as imagens publicadas conseguiam, de certa forma, construir atrativos e marcos para o passeio de automóvel. As fotografias de uma revista traduzem o pensamento do editor ou, no caso, daquilo que a AER queria transmitir para seus membros e demais leitores. Segundo Kossoy (2007, p. 104):

As imagens são concebidas e materializadas conforme as intenções de seus autores, segundo um filtro cultural e uma determinada visão de mundo. Tal se percebe claramente ao longo da história da fotografia e da própria história da imprensa.

O autor ainda afirma:

Se considerarmos que desde a passagem do século XIX para o XX as revistas ilustradas já tinham condições de reproduzir o meio tom fotográfico podemos imaginar a multidão de informações políticas, econômicas, sociais, geográficas, científicas, esportivas dentre outras inúmeras temáticas, além dos anúncios publicitários, que eram transmitidas por essas revistas. Os periódicos conservam, pois, um rico manancial de imagens que nos trazem dados sobre os mais diferentes aspectos do cotidiano urbano, rural e natural deste longo período (Kossoy, 2009, p. 96).

O caso em tela, a revista da APER, nasce em um contexto de imprensa, em São Paulo, muito interessante na segunda década do século XX. A capital paulista - e todo o estado, com o dinheiro da produção cafeeira e com a indústria em nascimento, queria se sobressair ao Rio de Janeiro e mostrar-se como liderança nacional. Então, o discurso e as imagens das revistas 
Silva, V., \& Allis, T. (2021, set./dez.). A construção do olhar do turista: uma análise iconográfica a partir da revista a estrada de rodagem $(1922-1923)$

paulistas e paulistanas do período, como as revistas de variedades "A Cigarra", "A Vida Moderna" e outras que tinham como público a elite letrada, destacava as ideias de modernidade e progresso.

Finalmente, coube às revistas, a função disseminadora da ideia do Progresso, vale dizer, do progresso paulista (...). Progresso foi a mensagem mais veiculada naquele periodismo para tornar atraente a cidade que se transformara em peça importante na engrenagem do capitalismo internacional (Martins, 2008, p. 564).

Também é necessário considerar a trajetória dessas imagens do passado, situando-as ao menos em três estágios que marcam sua existência: a intenção do fotógrafo ou de terceiros, a materialização a partir do registro fotográfico e caminhos percorridos por essas fotografias (Kossoy, 2009, p. 45).

\section{Metodologia}

A pesquisa foi baseada na análise de imagens coletadas por fotografia no acervo da Biblioteca e Hemeroteca do Arquivo Público do Estado de São Paulo, da coleção de revistas "A Estrada de Rodagem" e "Boas Estradas", como parte de uma pesquisa de mestrado, cujo repertório envolvia todas as 80 edições da revista. A dissertação não teve como objetivo estudar as imagens e sim os textos da publicação. Porém, durante o mestrado, houve contato com a metodologia de investigação iconográfica (Kossoy, 2009) e conhecimento da trilogia dos estudos da fotografia (Kossoy, 2009, 2007, 2002), o que levou à análise publicada neste artigo.

Neste trabalho, utilizando-se o modelo metodológico de investigação iconográfica, foram selecionadas e analisadas algumas fotos de reportagens da revista, em exemplares dos anos de 1922 e 1923. Para tanto, partiu-se do método proposto por Kossoy (2009), com interpretações e adaptações cabíveis ao acervo em questão. O modelo de Kossoy foi escolhido por proporcionar uma análise sistemática de uma reprodução impressa. Este modelo metodológico de investigação iconográfica é composto por duas fases, a análise iconográfica e a interpretação iconológica. Fazem parte da análise iconográfica o detalhamento sistemático do conteúdo da imagem, na qual Referência (REF) diz sobre o assunto ou tema principal, Identidade (ID) descreve os elementos que compõem a imagem como localização, procedência e pessoas envolvidas e Iconografia (ICON) refere-se à pesquisa de informações sobre a foto e o fotógrafo (Quadro 1). Esta primeira parte é descritiva, enquanto a interpretação iconológica busca a síntese dos significados da imagem a partir de todos os elementos analisados. 
Silva, V., \& Allis, T. (2021, set./dez.). A construção do olhar do turista: uma análise iconográfica a partir da revista a estrada de rodagem $(1922-1923)$

\section{Quadro 1}

Modelo Metodológico de Investigação Iconográfica

\begin{tabular}{|c|c|}
\hline $\begin{array}{l}\text { REF. } \\
\text { (Referência) }\end{array}$ & Assunto, Fotógrafo, Tecnologia (espaço tempo) \\
\hline $\begin{array}{l}\text { ID. } \\
\text { (Identidade) }\end{array}$ & $\begin{array}{l}\text { Identidade do documento + características individuais (registro, localização física, } \\
\text { procedência, conservação). }\end{array}$ \\
\hline \multirow{4}{*}{$\begin{array}{l}\text { ICON } \\
\text { (Iconografia) }\end{array}$} & Modalidade Artefato \\
\hline & $\begin{array}{l}\text { 1. Pesquisas referentes ao fotógrafo autor do registro (espaço, tempo) } \\
\text { 2. Pesquisas referentes ao assunto registrado (espaço, tempo) } \\
\text { 3. Pesquisas referentes à tecnologia empregada (espaço, tempo) }\end{array}$ \\
\hline & Modalidade reprodução impressa \\
\hline & $\begin{array}{l}\text { 1. Pesquisas referentes ao fotógrafo autor do registro (espaço, tempo) } \\
\text { 2. Pesquisas referentes ao assunto registrado (espaço, tempo) } \\
\text { 3. Tipologia e identificação do veículo (livro, periódico, cartaz, cartão postal, folheto, } \\
\text { catálogo, outros) }\end{array}$ \\
\hline
\end{tabular}

Nota: este quadro foi adaptado por Vânia da Silva e Thiago Allis para explicar, de maneira sucinta, o percurso metodológico da análise realizada neste trabalho, de Fotografia \& História (p. 100), de Kossoy, 2009, Ateliê Editorial.

Fonte: Autores.

Para a análise fotográfica das imagens na revista, não cabe a modalidade "artefato" que seria a própria foto revelada ou seu negativo, então, será usada a modalidade "reprodução impressa" que é o caso da reprodução fotográfica nas páginas da revista. Importante ressaltar que algumas das informações levantadas para a parte de Iconografia (ICON) da tabela não estão na página da fotografia, mas são resultantes da pesquisa feita nas 80 edições de "A Estrada de Rodagem" durante a dissertação.

Após a análise iconográfica (que terá foco em apenas uma imagem relevante) será feita uma breve interpretação iconológica, que consiste em entender a realidade interior daquelas imagens, buscando, a partir do contexto histórico, da reportagem e do perfil da revista, perceber quais intenções não estão aparentes, mas que fazem parte daquela fotografia (Kossoy, 2009, p. 101). Neste momento, a interpretação iconológica também se utilizará do conceito de viagens imaginativas de Urry e Larsen (2011).

Para tal exercício, foram selecionadas cinco reportagens com temas recorrentes na revista. Note-se que, com isso, busca-se proporcionar uma análise fragmentada do amplo acervo da revista, com o qual se pretende indicar caminhos para estudos de história do turismo que se baseiem em material iconográfico histórico, fartamente disponível em arquivos públicos e privados em muitos outros contextos.

O primeiro exemplo está em fotos de um grupo de excursionistas à Cachoeira do Marimbondo, no Rio Grande, entre São Paulo e Minas Gerais. O texto que acompanha as imagens não é referente ao assunto das fotos, que são explicadas somente pelas legendas. $\mathrm{O}$ 
Silva, V., \& Allis, T. (2021, set./dez.). A construção do olhar do turista: uma análise iconográfica a partir da revista a estrada de rodagem $(1922-1923)$

segundo exemplo é de uma imagem enviada por um associado de Santa Catarina e que foi publicada em uma página cujo texto também tratava de outro assunto sem referência com a imagem. O terceiro exemplo é de uma capa da revista. Os temas de capa eram fotos de estradas ou de monumentos, pontes e outros ícones rodoviários. Uma foto do presidente do estado, Washington Luís, cortando a fita de inauguração de uma estrada é o tema do quarto exemplo analisado; e a quinta matéria é o registro de uma excursão que partiu de São Paulo com destino a Ribeirão Preto.

\section{Resultados e discussão}

A seguir será exposto o resultado do exercício com as cinco reportagens, analisando as imagens no contexto em que foram capturadas e na forma como se inserem (ou não) na reportagem e no conteúdo da revista. Na sequência de cada imagem, quadros-resumo sintetizam os elementos iconográficos principais, aos quais se segue uma interpretação iconológica, onde buscamos identificar como elementos do turismo são incorporados à narrativa em construção. Essa sequência de ações, se muito comum nos estudos históricos, pode servir de referência para outros estudos de história do turismo, em que pese o emprego de imagens de arquivos e outros veículos de imprensa.

A primeira reportagem foi publicada em junho de 1922, e conta com algumas imagens (Figuras 1, 2 e 3), e retratam uma das excursões realizadas pelo interior do estado, com o uso de automóveis e participação de vários representantes da elite política e econômica de então. 
Silva, V., \& Allis, T. (2021, set./dez.). A construção do olhar do turista: uma análise iconográfica a partir da revista a estrada de rodagem $(1922-1923)$

\section{Figura 1}

Primeira Página da Reportagem “As Estradas de Rodagem no Interior”

\section{Aestrada \\ le Rodagem}

\section{AS ESTRADAS DE RODAGEM NO INTERIOR}

Felizmente já obtivemos resposta á quasi totalidade dos questronarios que no começo deste anno enviamos por 10 o littoral e interior do Estado, pedindo aos nossos delegados e aos prefeitos municipaes informaçes sobre as es. zdas de rodagem das respectivas regiões $e$ as commodidades de hospedagem, reparo e reaprovisionamento que nelle os vitas poderão estar certos de encontrar.

Infelizmente, porém, alguns poucos desses questionarios não foram ainda respondidos, o que nos tem impedido editarmos em livro todas as informações recebidas. Por esse motivo, pois, servimo-nos desse meio para pedirmos as ssôas a que nos dirigimos que nos façam o especial obsequio, no interesse geral, de preencherem com a maxima ur. ncia os questionarios que têm de nós recebido, em varias, devolvendo-os quanto antes a esta Associação.

CACONDE - Estradas (rafegaveis por au omoveis para hyquara (21 kilometros); Santo Antonio da Barra (18); coca (42); Guaxupé (30); São José do Rio Pardo (31); upiratiba (13; Guaranesia (33). Em projeclo a estrada ra São Jozé dos Botelhos (33). Melhor hotel: o Brasil $\mathrm{m}$ a diaria de $8 s$. Ha duas officinas para concertos de tos. Encontra-se gazolina na casa de M uuricio Famelli \& thos. São especialmente apraziveis os passeios á Usina ectrica e a Paradouro.

CASA BRANCA - Estradas para Palmeiras (16 kimetros); Tambahú (24); Engenheiro Roe (2!). Em conrucção a estrada para Vargem Grande (18), Melhor ho'el: offa, com a diaria de 105. Concertam-se autos na Garage
Rio Pardo (30); Santa Barbara do Rio Pardo (15). Melhor hotel: Hotel =D. Maria Assis", com a diaria de 88. Encontra-se gazolina na estação de Mandury

OI.YMPIA - Estradas para Barretos (48 kilomeiros) Icem (80); Rio Preto (95); Monte Azul (36); Baguassú (24); São Benedicto (16). Em projecto a rectificação da: estradas para Rio Preto, Tabapuan e Icem. Melhor hotel Grande Hotel, com a diaria de 88 . Ha duas officinas de concertos para autos. Encontra-se gazolina em varias partes da cidade.

ORLANDIA - Estradas para Batataes (30 kilometros); São Joaquim (30); Morro Agudo (20); Nuporanga

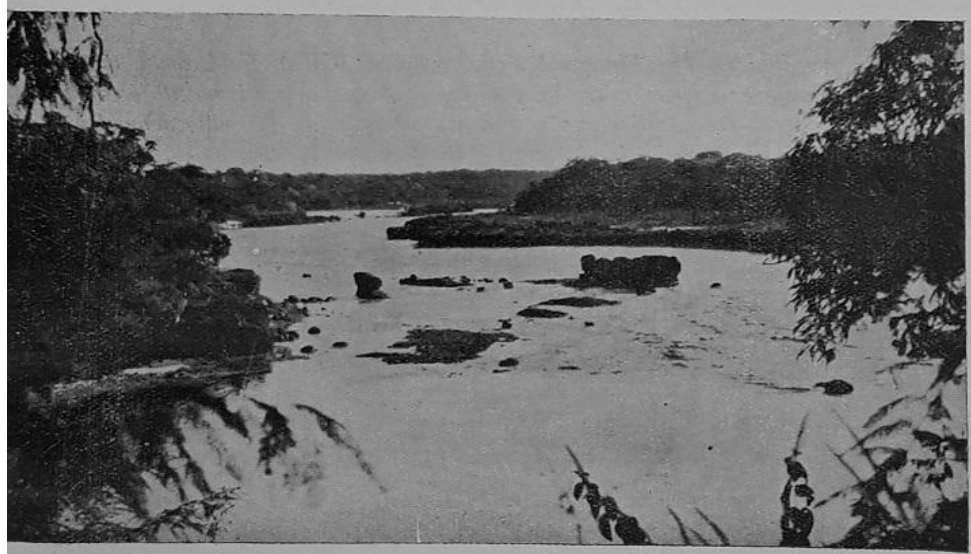

Esplendido TREcho DA CACHOEIRA DO MARIMBONDO, UM DOS MAIS BELLOS E INTERESSANTES MOTIVOS DE EXCURSÃO PELO interior do Estado. A PHOTOGRAPHIA REPRESENTA O RIO LOGO ABAIXO DE UMA DAS SUAS MUTTAS QUEDAS.

sportiva. Encontra-se gazolina nessa garage e na casa Manoè Cruz Palhavan. São especialmente apraziveis " passeios ao Parque Municipal e ao Rio Santa Anna.

NOVO HORIZONTE - Estradas para Itapolis (12 kimetros); Itajoby (20); Pirajuhy (24). Em construcçào a de ovo Horizonte para Irapoan (40). Melhor holel: Hotel essan, com a diaria de $8 \mathrm{~s}$. Concertam-se autos na Garage foderna. Encontra-se gazolina na referida garage, e nas asas Cadillo e Cabral. São especialmente apraziveis os asseios ao rín Tieté, ao rio Tres. Ponles e ao Porto errão.

OLEO - Estradas para a estação de Mandury (7 ki metros): estação Baptista Botelho (12); Santa Cruz do
15); Guahyra (16); Porto Dona Henriquela (54); Salles Oliveira $(7,450)$; Porto Santo Antonio (14) Melhor ho'el: - Hotel Orlandia com a diaria de 88. Concertam-se autos na Garage Bruza. Encontra-se gazolina nas casas de Joselino Cardose e Primo Azzi.

PALMEIRAS - Estradas para Pirassununga (30 kilometros); Casa Branca (18); Tambahú (15); Santa Cruz da Estrella (15); Santa Rita do Passa Quatro (35); Porto Ferreira (30). Ha ligação da séde do municipio para todas as fazendas nelle existentes. Melhores hoteis: Hotel Modelo e Hotel dos Viajantes. Ha trez officinas para concertos de autos. Encontra-se gazolina em algumas casas commerciaes.

Nota: Reproduzida de “As estradas de rodagem no interior”, revista “A Estrada de Rodagem”, n. 13, jun. 1922. Fonte: Arquivo Público do Estado de São Paulo. Domínio público. 
Silva, V., \& Allis, T. (2021, set./dez.). A construção do olhar do turista: uma análise iconográfica a partir da revista a estrada de rodagem $(1922$ - 1923)

\section{Figura 2}

Segunda Página da Reportagem "As Estradas de Rodagem no Interior”

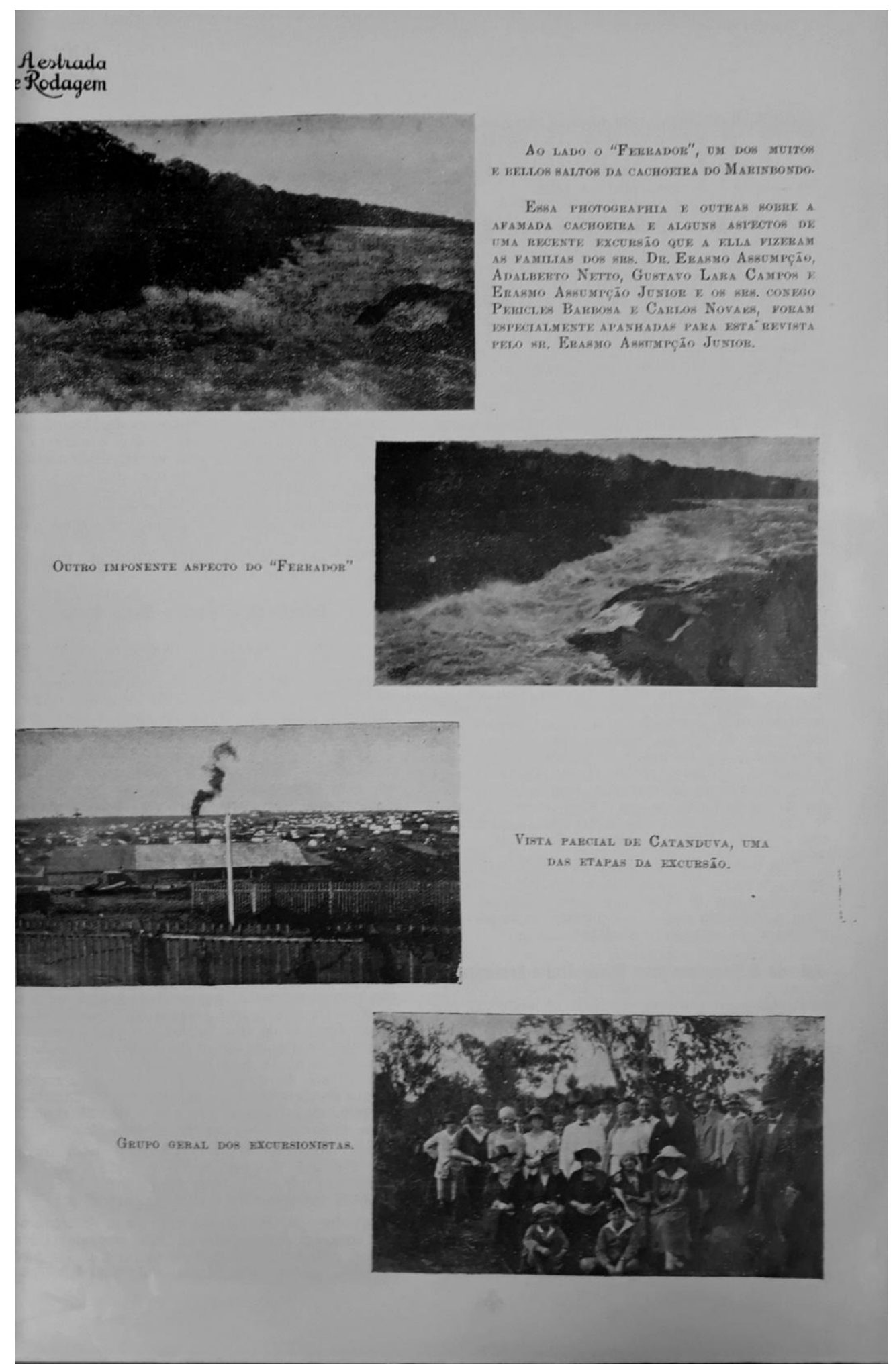

Nota: Reproduzida de "As estradas de rodagem no interior”, revista “A Estrada de Rodagem”, n. 13, jun. 1922. Fonte: Arquivo Público do Estado de São Paulo. Domínio público. 
Silva, V., \& Allis, T. (2021, set./dez.). A construção do olhar do turista: uma análise iconográfica a partir da revista a estrada de rodagem $(1922$ - 1923)

\section{Figura 3}

\section{Fotografia da Segunda Página da Reportagem "As Estradas de Rodagem no Interior"}

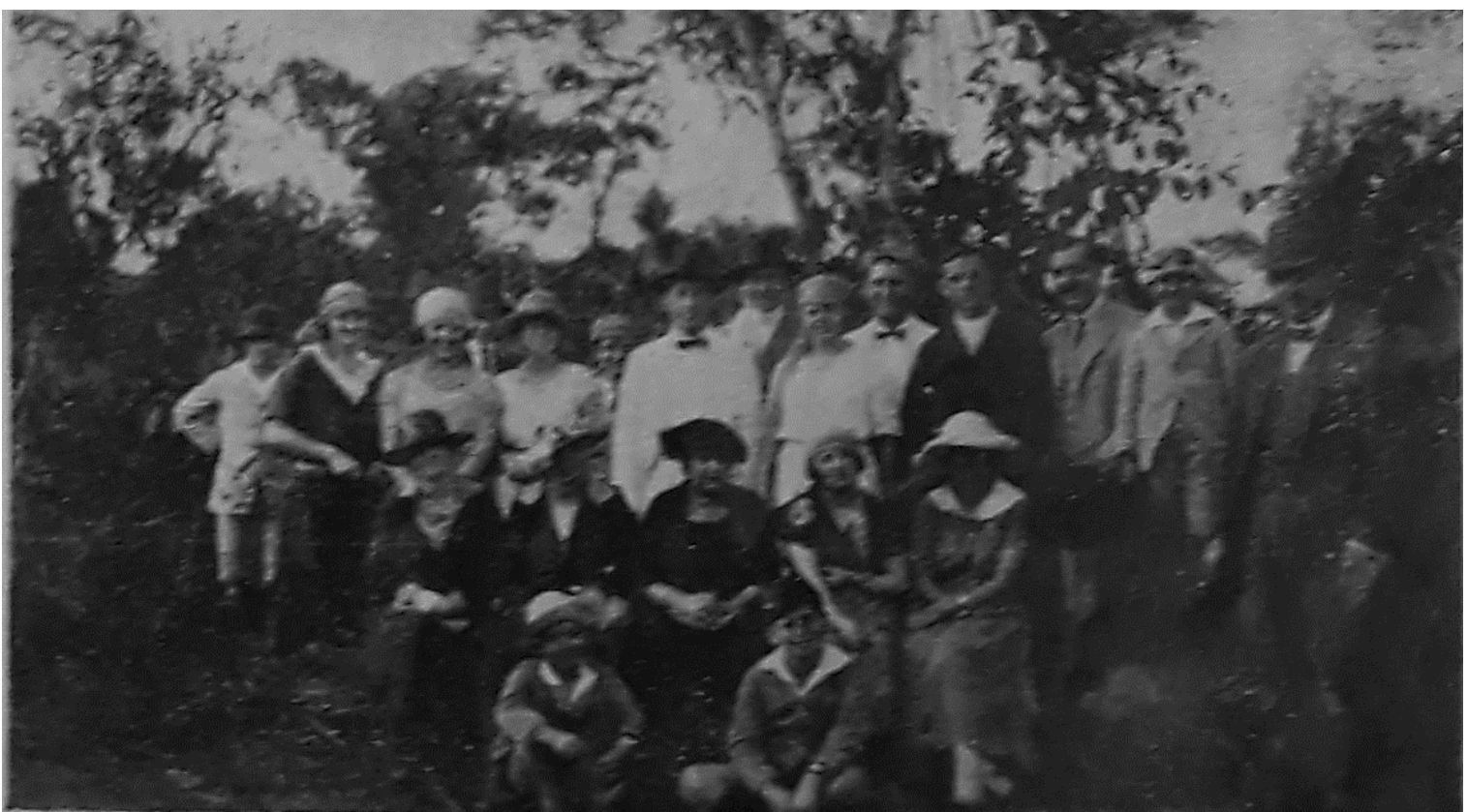

Nota: Reproduzida de "As estradas de rodagem no interior", revista “A Estrada de Rodagem”, n. 13, jun. 1922. Fonte: Arquivo Público do Estado de São Paulo. Domínio público.

\section{Quadro 2}

\section{Análise da Reportagem As Estradas de Rodagem no Interior}

\begin{tabular}{|c|c|}
\hline \multirow[b]{3}{*}{ REF. } & \\
\hline & Assunto, Fotógrafo, Tecnologia (espaço tempo) \\
\hline & $\begin{array}{l}\text { As legendas informam que se trata de uma excursão à Cachoeira do Marimbondo, Rio Grande, São } \\
\text { Paulo. Excursão feita pelas famílias dos senhores E. Assumpção, A. Netto, G. Lara Campos e E. } \\
\text { Assumpção Júnior, além de C. Péricles Barbosa e C. Novaes. Imagem impressa em preto e branco, } \\
\text { em papel couché ou similar, com brilho. Imagem escurecida (na impressão da revista). }\end{array}$ \\
\hline \multirow[b]{2}{*}{ ID } & $\begin{array}{l}\text { Identidade do documento + características individuais (registro, localização física, procedência, } \\
\text { conservação) }\end{array}$ \\
\hline & $\begin{array}{l}\text { Foto em destaque mostra o grupo de excursionistas, formado por membros de diferentes famílias. } \\
\text { São homens, mulheres e crianças vestidos formalmente. A foto é a última a ilustrar a matéria "As } \\
\text { estradas de rodagem no interior", da edição de junho de } 1922 \text { da revista "A Estrada de Rodagem". O } \\
\text { texto não faz referência às fotografias, tratando-se de assuntos independentes. Esse era um recurso } \\
\text { muito usado pela revista: usar fotos e fotos-legendas junto com textos que não tinham relação direta. } \\
\text { A imagem era inserida onde havia espaço nas páginas. } \\
\text { Ano: } 1922 \text { (da revista e, aparentemente, a imagem também é de 1922, devido à informação na } \\
\text { legenda da primeira fotografia da } 2^{a} \text { página, em que afirma ser "uma recente excursão"). } \\
\text { Procedência: imagem cedida pelos excursionistas. } \\
\text { Localização física: região da Cachoeira do Marimbondo. }\end{array}$ \\
\hline \multirow[b]{2}{*}{ ICON } & Modalidade reprodução impressa \\
\hline & $\begin{array}{l}\text { 1. Pesquisas referentes ao fotógrafo autor do registro (espaço, tempo): } \\
\text { E. Assumpção Júnior, associado à AER, enviou a foto. Dos citados na legenda, somente } \\
\text { ele e seu pai estavam na lista de associados de } 1925 \text { (a primeira publicada na revista). } \\
\text { 2. Pesquisas referentes ao assunto registrado (espaço, tempo): }\end{array}$ \\
\hline
\end{tabular}


Silva, V., \& Allis, T. (2021, set./dez.). A construção do olhar do turista: uma análise iconográfica a partir da revista a estrada de rodagem $(1922-1923)$

(Conclusão)

A Cachoeira do Marimbondo foi assunto na revista "A Estrada de Rodagem" em outros momentos, sendo a primeira vez neste registro acima.

Outra excursão à cachoeira foi publicada em julho. Ainda em setembro de 1922 publicou-se o texto "O que é a cachoeira de Marimbondo". Este não é um texto sobre turismo e sim sobre o potencial de geração de energia daquelas quedas d'água (somente em 1971 foi construída a Usina Hidrelétrica de Marimbondo no local).

Em setembro de 1923 foi feita nova reportagem, outro relato de viajantes, na seção de Turismo da revista: "Uma excursão automobilística - de São Paulo à Cachoeira dos Marimbondos e a várias cidades do interior: $1.540 \mathrm{~km}$ em estradas de rodagem".

3. Tipologia e identificação do veículo:

Periódico “A Estrada de Rodagem”, ano 2, no. 13, junho de 1922.

Nota: este quadro foi adaptado por Vânia da Silva e Thiago Allis para explicar, de maneira sucinta, o percurso metodológico da análise realizada neste trabalho, de Fotografia \& História (p. 100), de Kossoy, 2009, Ateliê Editorial

Fonte: Autores.

As Figuras 1, 2 e 3 destacam como a Cachoeira do Marimbondo é um dos primeiros "atrativos turísticos" com relato publicado na revista, inicialmente como registro fotográfico de uma excursão e, em duas outras oportunidades, como relato mais aprofundado em textos e fotos.

Esta é uma das poucas fotos da revista, publicada entre 1921 e 1928, em que aparece um grupo heterogêneo, com mulheres e crianças. A maior parte das fotos em que aparecem pessoas, é composta por homens - dirigentes e membros da Associação e de outras entidades do período. Estimulados pelo pedido que a revista fazia para seus leitores, de enviar registros fotográficos de seus passeios, os turistas da foto em destaque puderam ser vistos por outros leitores, despertando o interesse de realizarem o mesmo passeio e de estarem nas páginas da imprensa. A imagem é uma prova de que estiveram em excursão para a cachoeira, conforme frase de Sontag (2004), o registro fotográfico trouxe a comprovação do feito, disponível para os leitores da revista.

A publicação na revista não deve ter sido a intenção principal dos excursionistas, que queriam registrar a visita com o equipamento fotográfico. Mas, como sócios, fizeram a fotografia chegar aos editores, para mostrar a viagem em automóvel ao "ponto pitoresco" que era a cachoeira. Ao serem publicadas na revista, as imagens possibilitaram viagens imaginativas e despertaram o interesse de outros leitores em experimentar o percurso.

Nota-se, pela legenda, a preocupação em registrar os nomes de todas as famílias que participaram do evento. As pessoas estão em destaque na imagem, formalmente vestidas e comportadas. Afinal, esta foi uma excursão de uma associação automobilística que tinha uma imagem de seriedade a zelar. Nenhuma roupa de banho aparece, demonstrando que a visita à cachoeira pode ter sido para a contemplação da paisagem ou, simplesmente, o grupo poderia ter feito outros registros mais informais do passeio que não foram publicados. Afinal, não seria apropriado para os fotografados exporem-se em trajes de banho. 
Silva, V., \& Allis, T. (2021, set./dez.). A construção do olhar do turista: uma análise iconográfica a partir da revista a estrada de rodagem $(1922-1923)$

A segunda reportagem (Figura 4), publicada em setembro de 1922, destaca aspectos vantajosos das novas estradas de rodagem, em que a facilidade para fazer o turismo ganha algum destaque no argumento.

\section{Figura 4}

Primeira Página da Reportagem "As Vantagens das Estradas de Rodagem”

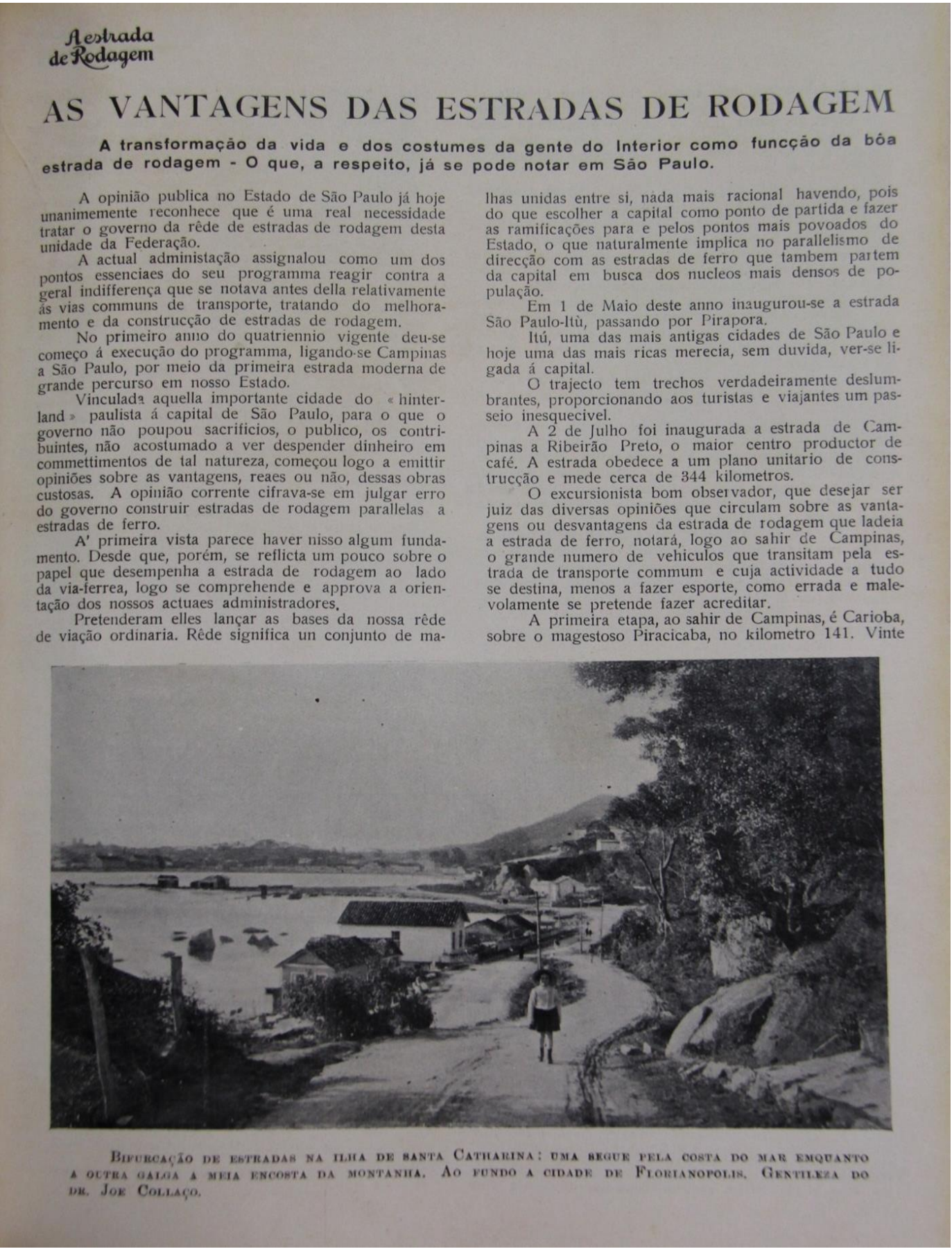

Nota: Reproduzida de "As vantagens das estradas de rodagem”, revista “A Estrada de Rodagem”, n. 15, set. 1922.

Fonte: Arquivo Público do Estado de São Paulo. Domínio público. 
Silva, V., \& Allis, T. (2021, set./dez.). A construção do olhar do turista: uma análise iconográfica a partir da revista a estrada de rodagem $(1922-1923)$

\section{Quadro 3}

Análise da Reportagem “As Vantagens das Estradas de Rodagem”

\begin{tabular}{|c|c|}
\hline \multirow[b]{2}{*}{ REF. } & Assunto, Fotógrafo, Tecnologia (espaço tempo) \\
\hline & $\begin{array}{l}\text { Estrada, trecho de estrada junto ao mar, rio ou lago, imagem impressa em preto e branco, em papel } \\
\text { couché ou similar, com brilho. }\end{array}$ \\
\hline \multirow[b]{2}{*}{ ID } & $\begin{array}{l}\text { Identidade do documento + características individuais (registro, localização física, procedência, } \\
\text { conservação) }\end{array}$ \\
\hline & $\begin{array}{l}\text { Foto ilustra a matéria “As vantagens da estrada de rodagem”, da edição de setembro de } 1922 \text { da revista } \\
\text { "A Estrada de Rodagem”. } \\
\text { Ano: } 1922 \text { (da revista, não necessariamente da imagem). } \\
\text { Procedência: imagem cedida por Joe Collaço (membro da AER), mas sem informações sobre o } \\
\text { fotógrafo. } \\
\text { Localização física: segundo a legenda, trata-se de uma bifurcação de estradas em Santa Catarina, } \\
\text { próximo a Florianópolis. }\end{array}$ \\
\hline \multirow[b]{2}{*}{ ICON } & Modalidade reprodução impressa \\
\hline & $\begin{array}{l}\text { 1. Pesquisas referentes ao fotógrafo autor do registro (espaço, tempo): } \\
\text { Quem enviou a foto foi Joe Luis Martins Collaço (1889-1951) que era advogado e foi deputado federal } \\
\text { em Santa Catarina por três mandatos seguidos, inclusive no ano de publicação da foto. Também foi } \\
\text { jornalista, um dos fundadores do jornal "O Estado" de Florianópolis, em 1915, e era proprietário do } \\
\text { jornal "Tribuna Popular" (Memória Política de Santa Catarina, 2020). } \\
\text { 2. Pesquisas referentes ao assunto registrado (espaço, tempo): } \\
\text { O texto da página em que se encontra a imagem não faz referência ao tema da fotografia (isso acontece } \\
\text { em muitas revistas do início do século XX, nem sempre a imagem é diretamente referente ao tema da } \\
\text { página, como exemplo analisado no Quadro 2). O texto é sobre estradas paulistas e nada diz sobre a } \\
\text { cena de Santa Catarina. Porém, pela legenda da foto, sabemos que é da bifurcação de uma estrada em } \\
\text { Santa Catarina, junto ao mar, bem próxima a Florianópolis. Na imagem tem uma menina andando pela } \\
\text { estrada vazia. Não há informações sobre sua identidade. 3. Tipologia e identificação do veículo (livro, } \\
\text { periódico, cartaz, cartão postal, folheto, catálogo, outros): } \\
\text { Periódico "A Estrada de Rodagem", ano 2, no. 16, setembro de } 1922 \text {. }\end{array}$ \\
\hline
\end{tabular}

Nota: este quadro foi adaptado por Vânia da Silva e Thiago Allis para explicar, de maneira sucinta, o percurso metodológico da análise realizada neste trabalho, de Fotografia \& História (p. 100), de Kossoy, 2009, Ateliê Editorial

Fonte: Autores.

Uma interpretação inicial para a escolha da imagem (Figura 4) pode ser a intenção de mostrar um passeio contemplativo "entre o mar e a montanha" como sugere a legenda. A imagem também diz ao leitor que era possível chegar a este local que não era servido por uma estrada de ferro (não aparecem trilhos na imagem) e ainda era possível escolher a pista junto ao mar ou aquela mais próxima da vegetação. Novamente, a imagem aguça a curiosidade do leitor em estar naquele lugar, de conhecer aquela paisagem catarinense, acessível por automóvel.

A criança que aparece na estrada está bem-vestida, posando para a câmera. Por isso, talvez não tenha sido uma fotografia encomendada pela Associação e sim uma colaboração, enviada pelo associado Joe Collaço para a entidade, com o objetivo de mostrar um aspecto de um passeio feito pela estrada de Santa Catarina com sua família. Sendo ele um político, talvez tenha colaborado para a abertura daquela estrada de rodagem e divulgar a imagem de sua cidade e estado para os membros da AER, como um cartão postal que convidava a uma viagem em 
Silva, V., \& Allis, T. (2021, set./dez.). A construção do olhar do turista: uma análise iconográfica a partir da revista a estrada de rodagem $(1922$ - 1923)

automóvel aos novos turistas. A foto transmite tranquilidade, como um cenário limpo, organizado, quase tão perfeito quanto uma pintura.

A foto enviada para a revista de São Paulo serviu como ilustração para a página. Mas também ajudou a AER a difundir um outro estado do Brasil que criava sua rede de estradas de rodagem. Dessa forma, reforçou a informação de que as estradas de rodagem estavam se viabilizando pelo país, convidando o leitor a aventurar-se em automóvel pelos novos caminhos.

Como já citado na primeira fotografia analisada (Figura 3), eram raras as imagens de mulheres e crianças nas páginas da revista da Associação. Esta foto é curiosa por destacar somente a menina, sozinha no meio da via, associada à ideia de futuro e da naturalidade no uso de estradas e automóveis.

A terceira matéria avaliada é, em realidade, a capa de um dos números da revista (Figura 5), mas que, por si só, põe em destaque elementos paisagísticos, de caráter antrópico, com apelo suficiente para se estimular um imaginário turístico. 
Silva, V., \& Allis, T. (2021, set./dez.). A construção do olhar do turista: uma análise iconográfica a partir da revista a estrada de rodagem $(1922$ - 1923)

Figura 5

Capa da Revista n. 19

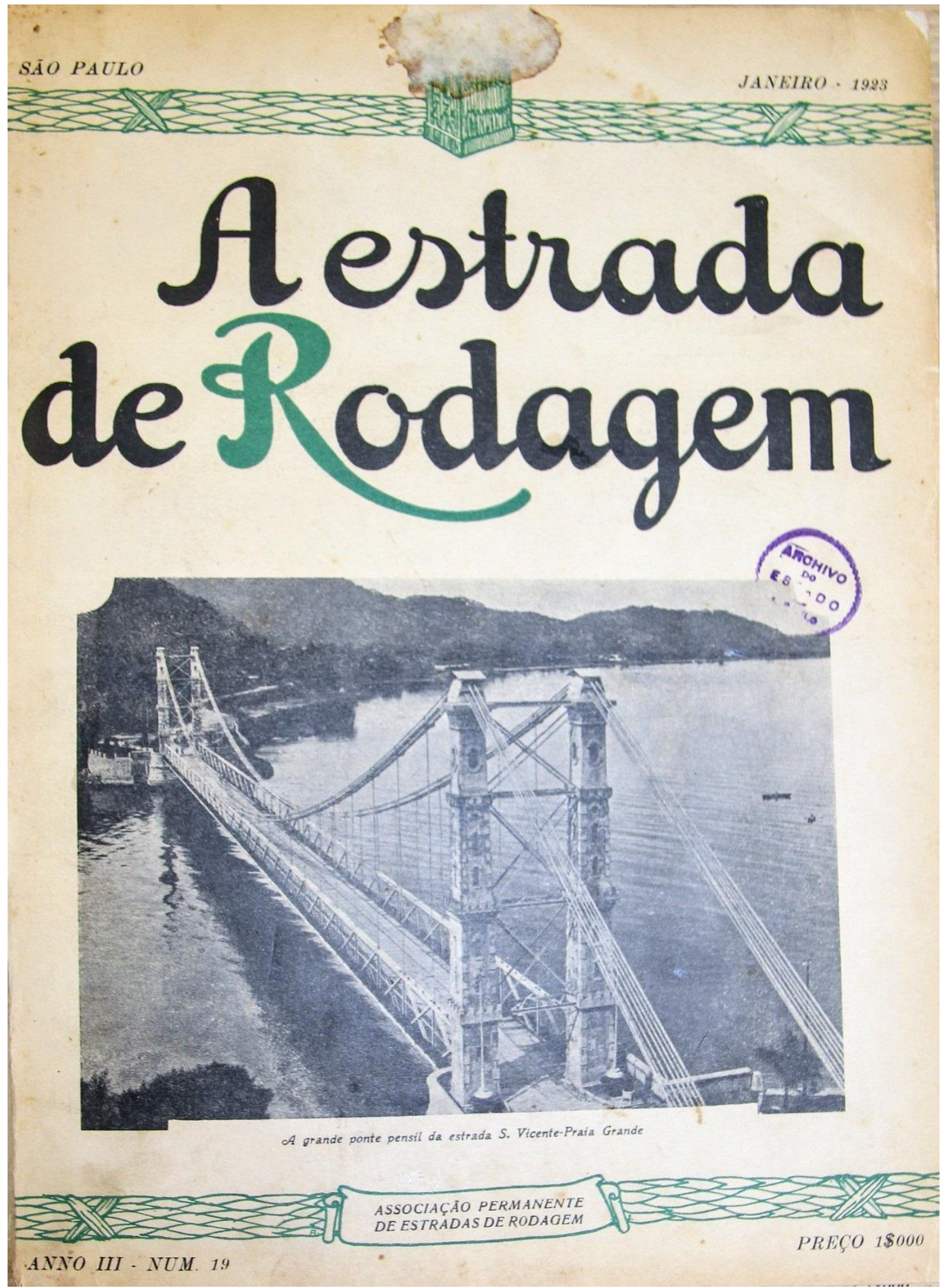

Nota: Reproduzida da capa da revista A Estrada de Rodagem, n. 19, jan. 1923.

Fonte: Arquivo Público do Estado de São Paulo. Domínio público. 
Silva, V., \& Allis, T. (2021, set./dez.). A construção do olhar do turista: uma análise iconográfica a partir da revista a estrada de rodagem (1922 - 1923)

\section{Quadro 4}

Análise da Imagem da Capa da Revista Número 19

\begin{tabular}{|c|c|}
\hline \multirow[b]{2}{*}{ REF. } & Assunto, Fotógrafo, Tecnologia (espaço tempo) \\
\hline & $\begin{array}{l}\text { Estrada de rodagem, ponte. Fotógrafo não identificado. Imagem impressa em preto e branco, na } \\
\text { capa de papel sem brilho. }\end{array}$ \\
\hline \multirow[b]{2}{*}{ ID } & $\begin{array}{l}\text { Identidade do documento + características individuais (registro, localização física, procedência, } \\
\text { conservação) }\end{array}$ \\
\hline & $\begin{array}{l}\text { Parece um registro aéreo, mostrando a ponte pênsil entre São Vicente e Praia Grande, no litoral de } \\
\text { São Paulo. }\end{array}$ \\
\hline \multirow[b]{2}{*}{ ICON } & Modalidade reprodução impressa \\
\hline & $\begin{array}{l}\text { 1. Pesquisas referentes ao fotógrafo autor do registro (espaço, tempo): } \\
\text { Na revista não há referência quanto ao responsável pela fotografia da capa desta edição. Em outro } \\
\text { exemplar (n. 16, setembro de 1922, meses antes da foto analisada ser publicada) uma nota agradece } \\
\text { Franck Temple Lethridge que seria o autor de muitas das belas fotografias da revista (sem mais } \\
\text { informações sobre essa pessoa ou sobre autoria das imagens). } \\
\text { 2. Pesquisas referentes ao assunto registrado (espaço, tempo): } \\
\text { A ponte pênsil São Vicente-Praia Grande foi inaugurada em } 21 \text { de maio de 1914, sendo a terceira no } \\
\text { Brasil, significando um grande avanço tecnológico para o litoral paulista (IPT). Não era uma novidade } \\
\text { para ser publicada na capa da revista, pois já existia há nove anos. Mas está ilustrando a capa por conta } \\
\text { de uma matéria sobre estradas do litoral paulista. } \\
\text { 3. Tipologia e identificação do veículo: } \\
\text { Revista "A Estrada de Rodagem", ano 3, no. 19, janeiro de } 1923 \text {. }\end{array}$ \\
\hline
\end{tabular}

Nota: este quadro foi adaptado por Vânia da Silva e Thiago Allis para explicar, de maneira sucinta, o percurso metodológico da análise realizada neste trabalho, de Fotografia \& História (p. 100), de Kossoy, 2009, Ateliê Editorial.

Fonte: Autores

Diversas fotos de pontes, monumentos e outros "símbolos da modernidade" estavam nas capas e páginas da revista, mostrando o domínio do homem sobre a natureza. Com a capa do seu número 19 (Figura 5), a Revista mostrava, assim, o progresso do estado de São Paulo na década de 1920, associado ao trânsito em automóvel, mudando a imagem de atraso em relação ao Rio de Janeiro, que era capital da República. Assim, assemelha-se ao processo de construção da imagem nacional no período imperial em que se pretendia substituir a imagem do Brasil selvagem para a de um Brasil civilizado.

A construção dessa imagem de Brasil é um processo dinâmico, moldando-se à ideologia de cada período, com a ajuda da fotografia (Kossoy, 2002, p. 106).

Muitas dessas pontes e monumentos tornaram-se atrativos turísticos e cartões postais do estado de São Paulo. Até os dias atuais a ponte pênsil é um marco do litoral paulista, muito mais como um elemento da paisagem do que um local de trânsito entre as cidades de São Vicente e Praia Grande.

A quarta matéria dá destaque para a inauguração de outro trecho de estrada de rodagem (Figuras 6 e 7), momento em que, oportunamente, se apresenta o turismo com uma das vantagens associadas. 
Silva, V., \& Allis, T. (2021, set./dez.). A construção do olhar do turista: uma análise iconográfica a partir da revista a estrada de rodagem $(1922-1923)$

\section{Figura 6}

Primeira Página da Reportagem "A Inauguração da Estrada São Paulo a São Roque”

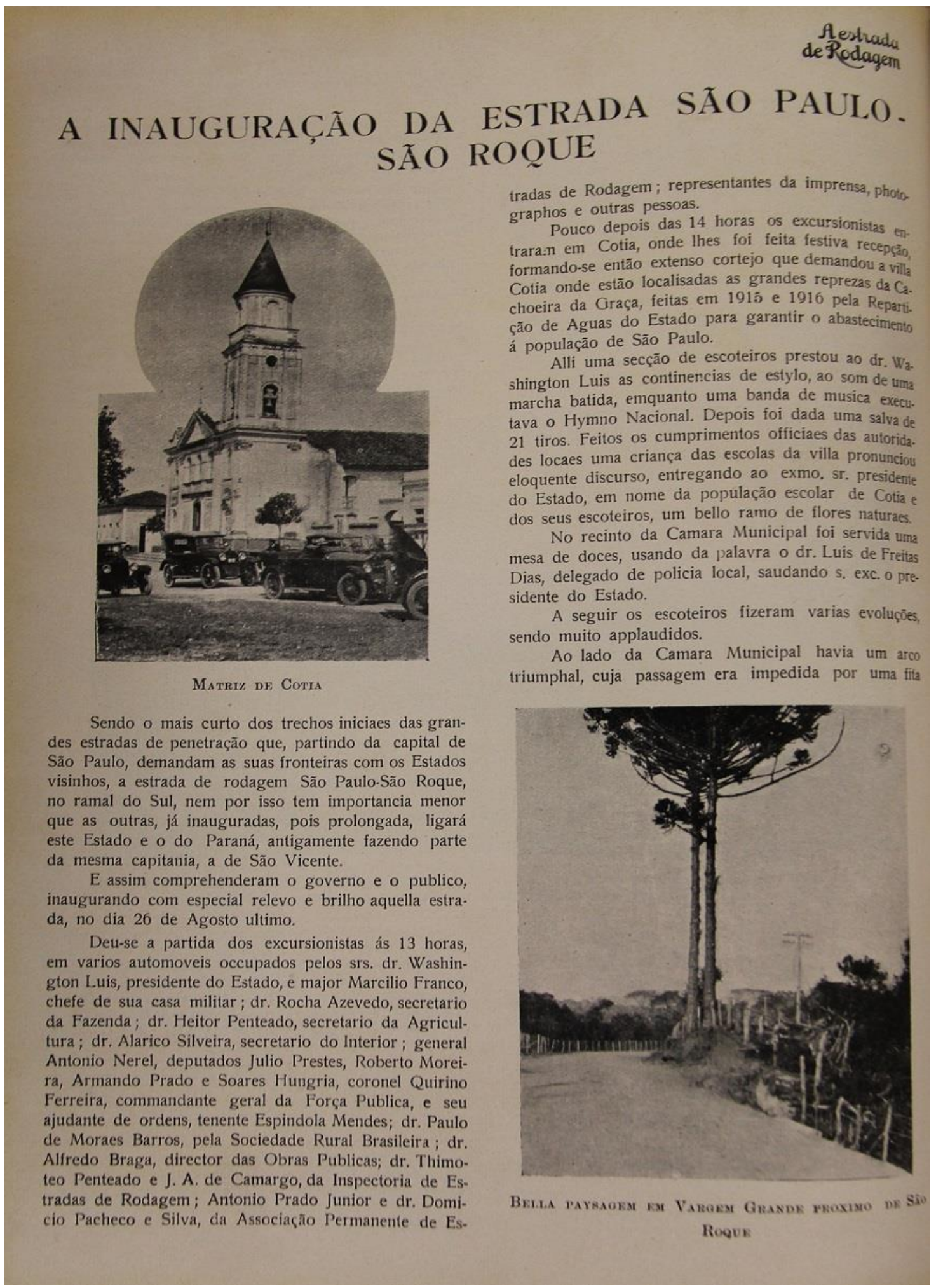

Nota: Reproduzida de "A inauguração da estrada São Paulo a São Roque", revista “A Estrada de Rodagem”, n. 15, set. 1922.

Fonte: Arquivo Público do Estado de São Paulo. Domínio público. 
Silva, V., \& Allis, T. (2021, set./dez.). A construção do olhar do turista: uma análise iconográfica a partir da revista a estrada de rodagem $(1922$ - 1923)

\section{Figura 7}

\section{Terceira Página da Reportagem “A Inauguração da Estrada São Paulo a São Roque”}

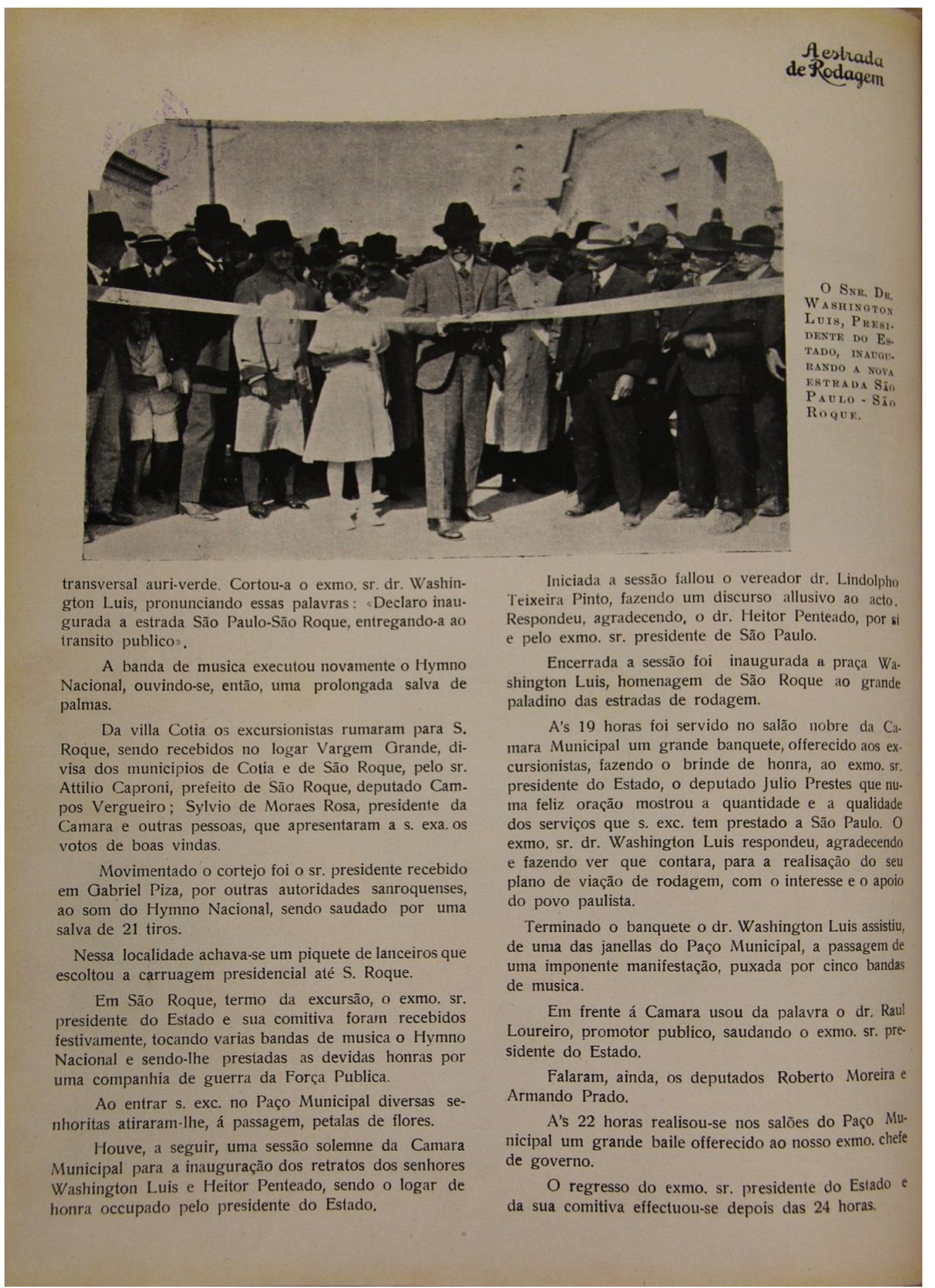

Nota: Reproduzida de "A inauguração da estrada São Paulo a São Roque", revista “A Estrada de Rodagem”, n. 15, set. 1922.

Fonte: Arquivo Público do Estado de São Paulo. Domínio público. 
Silva, V., \& Allis, T. (2021, set./dez.). A construção do olhar do turista: uma análise iconográfica a partir da revista a estrada de rodagem $(1922$ - 1923)

\section{Quadro 5}

\section{Análise da Reportagem "A Inauguração da Estrada São Paulo a São Roque”}

\begin{tabular}{|l|l|}
\hline \multirow{5}{*}{ REF. } & $\begin{array}{l}\text { Assunto, Fotógrafo, Tecnologia (espaço tempo) } \\
\text { Rutoridades e público na inauguração da estrada de rodagem que ligava as cidades de São Paulo e São } \\
\text { para São Roque; e de Washington Luís junto à faixa de inauguração. } \\
\text { Não existem informações sobre o fotógrafo. }\end{array}$ \\
\hline \multirow{5}{*}{ ID } & $\begin{array}{l}\text { Identidade do documento + características individuais (registro, localização física, procedência, } \\
\text { conservação) } \\
\text { Na imagem em destaque está o presidente do estado, Washington Luís, ao centro da foto, cortando a } \\
\text { fita (ou próximo à faixa de inauguração). Ele está cercado de homens, mas tem uma menina ao lado, } \\
\text { de vestido claro. Localização física é a cidade de São Roque. }\end{array}$ \\
\hline \multirow{5}{*}{ ICON } & $\begin{array}{l}\text { Modalidade reprodução impressa } \\
\text { 1. Pesquisas referentes ao fotógrafo autor do registro (espaço, tempo): } \\
\text { Sem informações quanto ao fotógrafo. Porém, o registro de atividades do governo estadual de } \\
\text { Washington Luís era feito oficialmente pela empresa Rossi Film, de Gilberto Rossi e José Medina } \\
\text { (Simis, 2015, p. 69). Mas não temos certeza se estas eram imagens oficiais ou de outros colaboradores. } \\
\text { 2. Pesquisas referentes ao assunto registrado (espaço, tempo): } \\
\text { Washington Luís era um grande incentivador da abertura de estradas pelo estado de São Paulo. } \\
\text { Participava de diversos eventos e instituições em prol dos esportes e do automobilismo. (Debes, 1993). } \\
\text { Ao contrário do apresentado nas figuras 1 a 4, as figuras 6 e 7 estão inseridas em uma reportagem. } \\
\text { Sendo o texto sobre a inauguração da estrada São Paulo - São Roque, ilustrando a narrativa. } \\
\text { 3. Tipologia e identificação do veículo: Revista "A Estrada de Rodagem", ano 2, no. 15, setembro de } \\
\text { 1922. }\end{array}$ \\
\hline
\end{tabular}

Nota: este quadro foi adaptado por Vânia da Silva e Thiago Allis para explicar, de maneira sucinta, o percurso metodológico da análise realizada neste trabalho, de Fotografia \& História (p. 100), de Kossoy, 2009, Ateliê Editorial.

Fonte: Autores.

A imagem 7 destaca a presença do presidente do estado, Washington Luís, inaugurando uma obra. Como um dos fundadores e grande incentivador da AER, o político sempre era citado na revista, seja por seus discursos favoráveis à abertura de estradas de rodagem ou por competições em seu nome, como provas automobilísticas feitas em sua homenagem. Talvez essa cobertura fotográfica tenha sido feita sob encomenda de Washington Luís pelos profissionais da Rossi Film. A reportagem fotográfica encontrou na revista da AER um veículo propício para propaganda do governador e das estradas de rodagem.

As imagens da reportagem mostram a cerimônia em torno da inauguração em São Roque, com a chegada de Washington Luís, o momento prévio ao corte da fita de inauguração e algumas imagens boas da estrada. Neste caso, as imagens também são importantes pelo que elas não mostram. Não se vê nesses registros pontos negativos como buracos na estrada, trechos interditados, lixo ou desordem. Sem ainda ter investigado a real situação desse trajeto entre São Paulo e São Roque naquele período, não se sabe o que ficou escondido do registro oficial. Dessa 
Silva, V., \& Allis, T. (2021, set./dez.). A construção do olhar do turista: uma análise iconográfica a partir da revista a estrada de rodagem $(1922$ - 1923)

forma, as imagens mostram um cenário ideal e a preocupação do governo em abrir estradas para diversos usos, inclusive para o turismo.

O político, cortando a fita de inauguração, prestigiava a cidade de São Roque e esta passava a ter visibilidade para ser conhecida, visitada e explorada em automóvel - com a chancela e estímulo político, representado pelo mandatário do estado. Ainda que o turismo e, por conseguinte, a comunicação turística fossem muito rústicos nesta época, situações como esta concorrem para a promoção de um imaginário turístico ainda em elaboração no contexto social de então. A imagem é o desfecho ideal para a matéria, que mostrava outras imagens do caminho e ajudavam a estimular viagens imaginativas - para, em outros momentos, estimular fluxos efetivos de visitantes.

A quinta matéria analisada inaugura uma nova seção da revista, que, de maneira mais explícita, vai alinhar elementos editoriais no campo do turismo. Como se verá (Figuras 8 e 9), a dimensão imagética vai ganhando mais espaço, especialmente porque, quanto mais estradas são abertas, mais paisagens e experiências são descortinadas para o futuro visitante. 
Silva, V., \& Allis, T. (2021, set./dez.). A construção do olhar do turista: uma análise iconográfica a partir da revista a estrada de rodagem $(1922-1923)$

\section{Figura 8}

Terceira Página da Reportagem “Os Itinerários da A.P.E.R.”

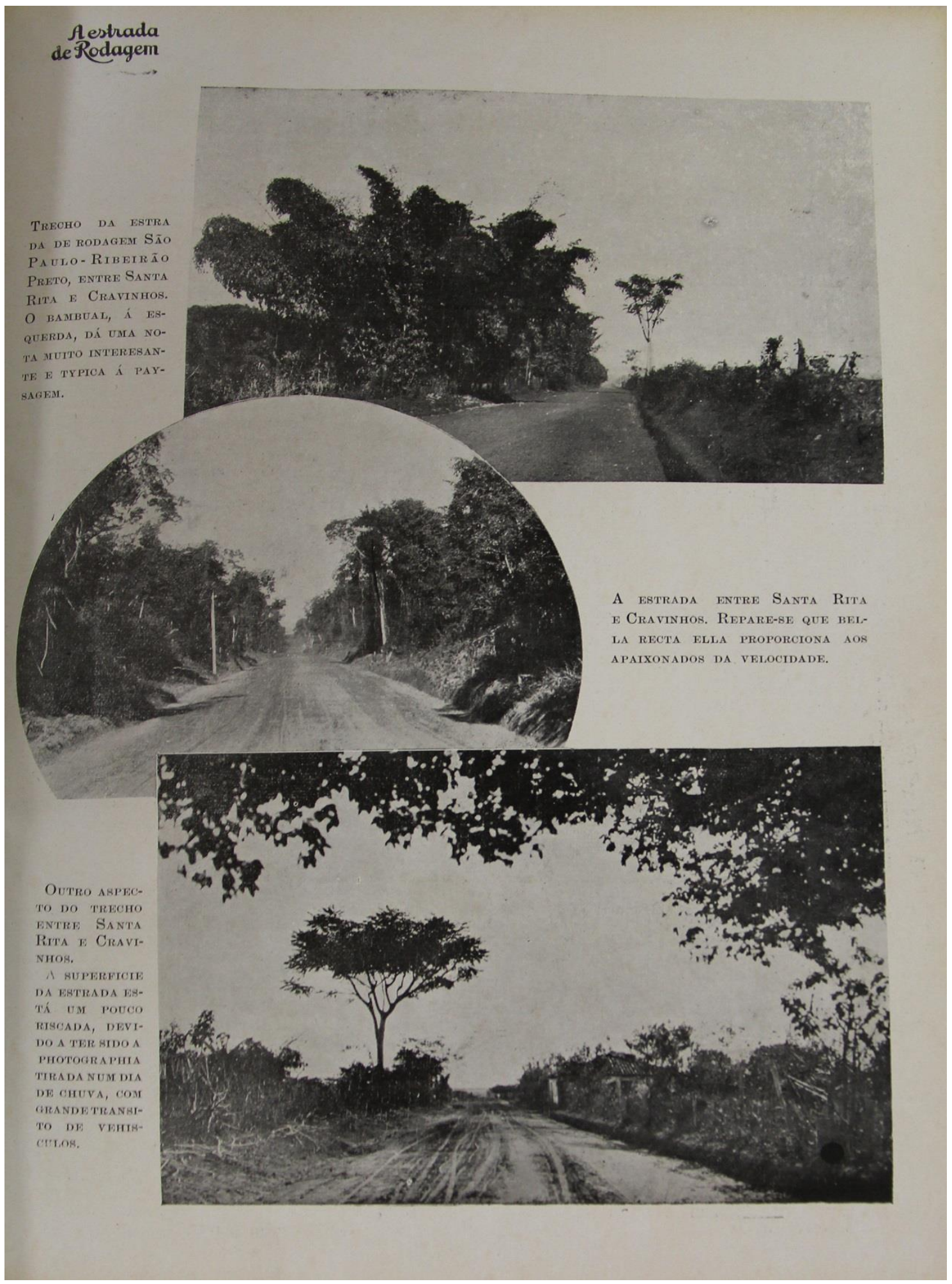

Nota: Reproduzida de "Os itinerários da A.P.E.R.", revista “A Estrada de Rodagem’, n. 14, ago. 1922. Fonte: Arquivo Público do Estado de São Paulo. Domínio público. 
Silva, V., \& Allis, T. (2021, set./dez.). A construção do olhar do turista: uma análise iconográfica a partir da revista a estrada de rodagem $(1922-1923)$

\section{Figura 9}

Fotografia da Terceira Página da Reportagem “Os Itinerários da A.P.E.R.”

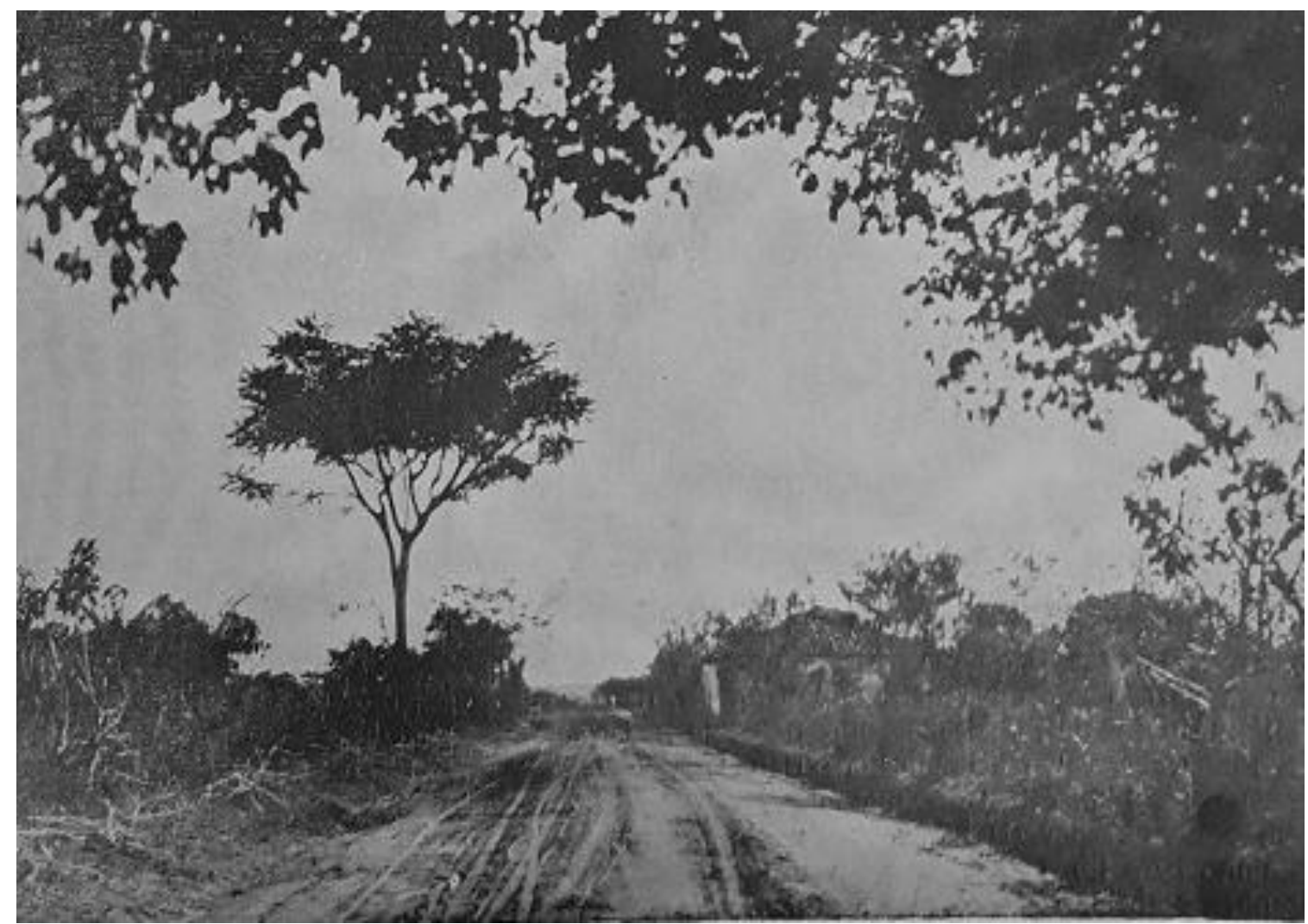

Nota: Reproduzida de "Os itinerários da A.P.E.R.", revista “A Estrada de Rodagem”, n. 14, ago. 1922.

Fonte: Arquivo Público do Estado de São Paulo. Domínio público.

\section{Quadro 6}

Análise da reportagem "Os itinerários da A.P.E.R.”

(continua)

\begin{tabular}{|c|c|}
\hline \multirow[b]{2}{*}{ REF. } & Assunto, Fotógrafo, Tecnologia (espaço tempo) \\
\hline & $\begin{array}{l}\text { Aspectos de uma excursão de automóvel de São Paulo a Ribeirão Preto, com várias imagens do que se } \\
\text { encontra pelo caminho e de locais da cidade de encerramento da viagem. A imagem em destaque é de } \\
\text { um trecho da estrada entre Santa Rita e Cravinhos. }\end{array}$ \\
\hline \multirow[b]{2}{*}{ ID } & $\begin{array}{l}\text { Identidade do documento + características individuais (registro, localização física, procedência, } \\
\text { conservação) }\end{array}$ \\
\hline & $\begin{array}{l}\text { Na foto em destaque está um trecho da estrada em que aparece a vegetação em volta e diversas marcas } \\
\text { de pneus no chão. Então, supõe-se que seja uma estrada de terra (ao menos parte dela). Também é citada } \\
\text { na legenda a informação de que há um grande trânsito de veículos por essa estrada e que a foto foi tirada } \\
\text { num dia de chuva, evidenciado pelas marcas de pneus. }\end{array}$ \\
\hline \multirow[b]{2}{*}{ ICON } & Modalidade reprodução impressa \\
\hline & $\begin{array}{l}\text { 1. Pesquisas referentes ao fotógrafo autor do registro (espaço, tempo): } \\
\text { Não é citado o autor das fotos. Seria um dos excursionistas, que pode ter sido um representante da } \\
\text { Associação. } \\
\text { 2. Pesquisas referentes ao assunto registrado (espaço, tempo): } \\
\text { A viagem de São Paulo a Ribeirão Preto tem cerca de } 300 \text { quilômetros e passa por diversas cidades de } \\
\text { grande importância econômica para o estado, como Campinas, Limeira e Piracicaba. Destacam ser a } \\
\text { estrada mais longa do estado até então. Na matéria são apresentados alguns locais que mostram o }\end{array}$ \\
\hline
\end{tabular}


Silva, V., \& Allis, T. (2021, set./dez.). A construção do olhar do turista: uma análise iconográfica a partir da revista a estrada de rodagem $(1922-1923)$

(Conclusão)

desenvolvimento da cidade de Ribeirão Preto, como suas instalações metalúrgicas e a praça principal. A legenda destaca um trecho reto da estrada, propício para andar em alta velocidade.

3. Tipologia e identificação do veículo: Revista “A Estrada de Rodagem”, ano 2, no. 14, agosto de 1922.

Nota: este quadro foi adaptado por Vânia da Silva e Thiago Allis para explicar, de maneira sucinta, o percurso metodológico da análise realizada neste trabalho, de Fotografia \& História (p. 100), de Kossoy, 2009, Ateliê Editorial.

Fonte: Autores.

Os “Itinerários da A.P.E.R.” eram uma espécie de roteiro turístico em que se ofereciam diversas informações sobre um trajeto por estrada, com automóvel. Os Itinerários foram substituídos pela seção “Turismo” em 1923. Na reportagem chamam atenção, além dos diversos pontos da estrada, informações sobre a metalúrgica na cidade de Ribeirão Preto, mostrando a industrialização e progresso da cidade. Essas fotografias podem despertar o interesse do leitor em conhecer tão simpático roteiro, ao mesmo tempo em que fortalece a boa imagem da região perante as demais do estado, passando a ideia de progresso e prosperidade.

Quanto à imagem em destaque, em que a estrada está com marcas de pneus, a intenção talvez tenha sido mostrar que era uma estrada de muito trânsito pela quantidade de marcas deixadas, mas acabou revelando a fragilidade do solo em dias de chuva. Talvez seja um trecho sem calçamento resistente e isso era uma exceção em imagens mostradas pela revista. Geralmente eram evidenciados apenas os aspectos positivos das estradas e quase nunca suas fraquezas ou desvantagens. Porém, também apresentava um caminho livre, sem trânsito, atrativo para um passeio em automóvel, apreciando a passagem, longe da cidade. Muitas imagens semelhantes eram mostradas na revista.

\section{Interpretação histórica através de fotografia como contribuição para a história do turismo}

A análise iconográfica e a interpretação iconológica das reproduções em revista permitiram um olhar mais atento para alguns registros fotográficos da revista "A Estrada de Rodagem" nos anos de 1922 e 1923. O detalhamento de itens da metodologia de análise faz o levantamento de informações importantes para a reconstrução do momento passado, trazendo aspectos que, talvez, passassem despercebidos ao primeiro olhar.

A partir desses elementos detalhados é possível realizar a interpretação iconológica que permite refletir sobre diversos aspectos da construção da imagem e da mensagem que o autor da fotografia queria passar para o leitor, além de permitir conhecer o foco da linha editorial da revista, tais como: a) relações de gênero, b) olhares sobre a paisagem (composição entre elementos humanos e naturais), c) a valorização da sensação de poder e liberdade atribuídas às 
Silva, V., \& Allis, T. (2021, set./dez.). A construção do olhar do turista: uma análise iconográfica a partir da revista a estrada de rodagem $(1922$ - 1923)

estradas e ao automóvel, d) a construção de novos cartões postais com sotaque paulista, entre outros aspectos.

Os elementos destacados, de alguma forma, ajudaram a aguçar o olhar do leitor (aqui assumido como um "proto-turista”) para a apreciação das viagens em automóvel pelas estradas paulistas. Vale lembrar que, na década de 1920, viajar em automóvel era uma opção quase insólita, com tom de aventura - quando o estado de S. Paulo se aproximava de atingir o ápice de extensão da rede ferroviária. Portanto, promover o uso do automóvel poderia ser entendido quase como um contrassenso - não fossem as simbologias e intenções subjacentes, como demonstrado pelas análises acima.

As imagens da publicação trazem estradas e locais de interesse turístico como cachoeiras, igrejas, pontes e monumentos; muitas imagens apresentadas são apenas das estradas vazias, sem pessoas, construções ou carros. De qualquer forma, convidam a diversas viagens, pequenas ou grandes excursões, para os novos proprietários de automóveis. Pelas páginas da revista, o leitor ou assinante associado tinha em mãos, mensalmente, muitas possibilidades de roteiros a serem explorados, de forma imaginativa, num primeiro momento, e, se se convencesse e dispusesse de meios, real.

As reportagens permitiam viagens imaginativas na medida em que mostravam fotografias de cidades acessíveis por caminhos aparentemente fáceis de atravessar com automóvel. Essas imagens também são importantes pelo que não mostram: pobreza, perigo, insegurança. Ao contrário, as fotografias das reportagens selecionadas trazem estradas limpas, livres de riscos como buracos e penhascos. As pessoas aparentam ser bem-sucedidas, pois estão com roupas formais e sorrindo para a câmera. A autoridade está presente inaugurando uma estrada em uma festa para a cidade; outra imagem traz a imponente ponte pênsil, limpa e bela, com arrojo técnico que vence limitações da natureza. Todas essas informações - de maneira ainda precoce, se considerado o histórico do turismo no Brasil e ainda mais em São Paulo estimulam o leitor a imaginar que o automóvel e as estradas são benéficas e trazem o progresso, instigando a vontade de viajar por elas e fazer parte desse grupo também.

As pessoas aparecem quando a foto é de um evento (como a reportagem sobre a inauguração da estrada de São Paulo a São Roque, em que aparecem autoridades, principalmente). Também surgem esporadicamente em grupos de excursionistas (no caso da reportagem sobre a Cachoeira de Marimbondo). Ou seja, as estradas de rodagem eram apresentadas não apenas como infraestrutura (elemento técnico), mas também como espaço para novas sociabilidades em movimento (elemento social e cultural). Esses relatos reforçam o 
Silva, V., \& Allis, T. (2021, set./dez.). A construção do olhar do turista: uma análise iconográfica a partir da revista a estrada de rodagem $(1922-1923)$

papel de difusão do turismo em estradas de rodagem, que não era o objetivo principal da Associação, mas que estava entre as possibilidades de uso da estrada.

Ao mesmo tempo, são destacadas as imagens de construção de estrada e da tecnologia que ergue marcos e ícones como a Ponte Pênsil, em São Vicente, no litoral que ainda se estruturava como referência para o turismo balnear. O progresso era a pauta - pouco se falava sobre a preservação de florestas e sobre o contato com a natureza que as viagens proporcionariam. Algumas pautas ressaltam a fuga da cidade com o automóvel e sobressai a ideia de chegar ao destino com o automóvel, passear pelas estradas e parar no caminho para apreciar a paisagem, comer e repousar. Este é um ponto que, por mais que sutil, promove uma ideia ainda hoje vigente no imaginário turístico: o de liberdade, de fazer o roteiro por onde e como bem entender, privadamente, não dependendo de rotas, horários e grupos fixos, tal como em geral já se observava com o pouco de turismo que se insinuava com o uso das ferrovias de então.

\section{Considerações finais}

Esta análise - que, por óbvio, merece articulações mais estruturadas com outras pesquisas historiográficas - indica que, ainda que em tom quase anedótico, o turismo que começava a se esboçar no período representava um instrumento para a difusão de poderio econômico e político de São Paulo. Assim, em um plano histórico mais alargado, podemos argumentar que - mesmo que através de práticas muito sutis - o turismo teve uma relevância simbólica muito destacada no período, algo que, nas décadas seguintes, seria suplantada pelas práticas turísticas fora do estado (conforme a economia paulista se expandia, gerando demandas turísticas para outras partes do país).

Note-se que, apesar de uma amostra bem reduzida, o exercício analítico deste artigo aponta para um relevante potencial interpretativo tanto no que se refere à construção de historiografia do turismo no país, quanto no estudo sobre o exercício de poder e intenções - em que o turismo, neste caso, aparece como mecanismo intermediário. Havia, como se sabe, uma disputa simbólica no plano político nacional: entre um estado (São Paulo) que se industrializava mas continuava na periferia do sistema político, e outro (Rio de Janeiro) que mantinha uma centralidade política, ainda que, paulatinamente, fosse perdendo proeminência econômica diante da dispersão do desenvolvimento nacional. Assim, a revista - e, de maneira indireta, o turismo nascente - representam esforços para convencer, primeiro, uma elite paulista de que 
Silva, V., \& Allis, T. (2021, set./dez.). A construção do olhar do turista: uma análise iconográfica a partir da revista a estrada de rodagem $(1922-1923)$

era necessário investir nas "modernidades" rodoviárias e, de maneira mais ampla, promover a integração do território estadual de maneira alternativa ao intrincado - mas rígido - sistema ferroviário.

Do ponto de vista teórico-metodológico, o trabalho iconológico com estes cinco exemplos - ainda que específicos de um contexto histórico e geográfico - aponta para um caminho de investigação em turismo mais ampliado, o que, com pouca dúvida, contribuiria para um entendimento mais detalhado sobre as representações sociais e as intenções de políticas públicas vinculadas ao turismo no passado e no presente. A despeito de o turismo ser uma atividade quase inexistente neste período, a análise pormenorizada de uma publicação indica esforços coordenados de determinados setores políticos e econômicos para promover um ideal de turismo - associado às promessas de liberdade e experiências proporcionadas pelo automóvel e pelas viagens rodoviárias. Ou seja, ainda que o conceito de "viagens imaginativas" tenha sido estruturado apenas recentemente, notamos que - por um esforço de imprensa e coordenação política - alguns agentes já se organizavam há quase 100 anos para seduzir e convencer públicos específicos sobre as possibilidades de viajar (neste caso, com carro e pelas recém-inauguradas estradas de rodagem). Esta lógica, tão presente e quase banalizada com a dispersão das redes sociais no século XXI, já estava se constituindo em São Paulo, quando a própria ideia de viajar era ainda associada a roteiros exclusivos para as elites (que buscavam a Europa) ou as transumâncias e migrações mandatórias - sem qualquer conotação de prazer.

De maneira geral, podemos argumentar, portanto, que a análise do turismo em um contexto muito específico colabora para uma estruturação mais ampla do turismo como área de estudo, ao incorporar fenômenos nativos ao processo reflexivo ainda muito dependente dos relatos históricos internacionais.

Somando todas as interpretações iconológicas, percebe-se, mesmo nesta pequena amostra, que há um esforço da publicação em mostrar nas imagens o que foi bem-sucedido em termos de construção de estradas de rodagem.

O registro fotográfico naquele momento ajudou a formar a iconografia do turismo em estradas paulistas. A câmera eternizava o momento inédito, registrando caminhos ainda desconhecidos, convidando a explorar esses novos caminhos e paisagens, alguns deles que não estavam acessíveis em viagens de trem. Nesta amostra, estão imagens que ajudaram a criar cartões postais paulistas. Conforme Urry \& Larsen (2011, p. 186), o desenvolvimento da fotografia foi fundamental para o aperfeiçoamento do olhar do turista e do turismo. A fotografia e o olhar do turista não são dissociados e atuam como instrumentos em uma orquestra que, 
Silva, V., \& Allis, T. (2021, set./dez.). A construção do olhar do turista: uma análise iconográfica a partir da revista a estrada de rodagem $(1922-1923)$

juntos, criam música. A fotografia e o olhar em movimento colaboram para a construção cultural do turismo.

O olhar do turista é elaborado discursivamente e materialmente por meio de imagens, resultado da fotografia na revista, da paisagem ou do objeto fotografado. Há aqui um potencial a ser explorado ao analisar fotografias de turismo feito no passado, que ajudam a entender a sociedade, seus hábitos e modismos, desde que embasada em conhecimento histórico.

Como sugestão para pesquisas futuras, abre-se um amplo escopo de análise a partir da imprensa especializada ou não, buscando aprofundamentos em conteúdos jornalísticos ou mesmo de propagandas, que seriam importantes para entender a participação do turismo no modus vivendi de distintas épocas. Nestas, a depender do contexto, o turismo poderá estar sendo gestado, ainda que de maneira pouco explícita, a ponto de encontrarmos novas e elucidativas fontes sobre a história do turismo no Brasil, mas também sobre como esta prática se constituiu como fenômeno social complexo.

\section{Referências}

A inauguração da estrada São Paulo a São Roque. (1922, Setembro). A Estrada de Rodagem, 15.

As estradas de rodagem no interior. (1922, Junho). A Estrada de Rodagem, 13.

As vantagens da estrada de rodagem. (1922, Setembro). A Estrada de Rodagem, 15.

Capa. (1923, Janeiro). A Estrada de Rodagem, 19.

Castro, C. (2001). A Natureza Turística do Rio de Janeiro. In: A. Banducci, M. Barreto (Ed.), Turismo e identidade local: uma visão antropológica. (Coleção Turismo, pp. 117125). Papirus.

Debes, C. (1993). Washington Luís (1869-1924). Imprensa Oficial do Estado de São Paulo.

Giucci, G. (2004). A vida cultural do automóvel: percursos da modernidade cinética. Civilização Brasileira.

IPT. (s.d.). 100 anos da ponte pênsil de São Vicente. Recuperado de: www.ipt.br/institucional/campanhas/42100_anos_da_ponte_pensil_de_sao_vicente.ht $\mathrm{m}$.

Kossoy, B. (2002). Realidades e ficções na trama fotográfica. Ateliê Editorial.

Kossoy, B. (2007). Os tempos da fotografia: o efêmero e o perpétuo. Ateliê Editorial.

Kossoy, B. (2009). Fotografia \& História. $3^{\text {a }}$ ed. Ateliê Editorial. 
Silva, V., \& Allis, T. (2021, set./dez.). A construção do olhar do turista: uma análise iconográfica a partir da revista a estrada de rodagem $(1922$ - 1923)

Martins, A. L. (2008). Revistas em revista: imprensa e práticas culturais em tempos de República. São Paulo (1890-1922). EDUSP, Fapesp.

Memória Política de Santa Catarina. (2020). Biografia Joe Collaço. Recuperado de http://memoriapolitica.alesc.sc.gov.br/biografia/508-Joe_Collaco. Acesso em: 2021$06-25$

Os itinerários da A.P.E.R. (1922, Julho). A Estrada de Rodagem, 14.

Pereira, R. M. (2010). Washington Luís na administração de São Paulo (1914-1919). Editora UNESP.

Reis, N. G. (1998). Cultura e estratégias de desenvolvimento. Caderno pesquisa LAP. FAUUSP.

Silva, V. (2019). Mobilidades e viagens imaginativas: o papel da Associação de Estradas de Rodagem para o turismo em São Paulo (1919-2019). Dissertação (Mestrado em Desenvolvimento do Turismo) - Escola de Artes, Ciências e Humanidades, Universidade de São Paulo, São Paulo, 2019. DOI: https://doi.org/10.11606/D.100.2019.tde-19112019-171501. Acesso em: 2021-06-25.

Simis, A. (2015). Estado e cinema no Brasil. Editora Unesp.

Sontag, S. (2004). Sobre fotografia. Companhia das Letras.

Urry, J. \& Larsen, J. (2011). The tourist gaze 3.0.Sage.

Urry, J. (2007). Mobilities.: Polity Press. 